\title{
Rectal Mucositis
}

National Cancer Institute

\section{Source}

National Cancer Institute. Rectal Mucositis. NCI Thesaurus. Code C78584.

An inflammatory process affecting the mucous membrane of the rectum. 